\title{
Editorial
}

\section{Debutando em Grande Estilo}

\author{
"A mente que se abre a uma nova idéia \\ jamais voltará ao seu tamanho original”
}

Albert Einstein

Em cumprimento ao anunciado em números anteriores, com este primeiro número do volume 27 da revista Psicologia: Teoria e Pesquisa, inauguramos a periodicidade trimestral de publicação e passamos a operar na plataforma SEER de tramitação eletrônica. Esperamos com essas duas mudanças radicais, atender à crescente demanda de divulgação da produção científica na área da psicologia, bem como corresponder às exigências associadas à qualificação de excelência de nosso periódico. Pretendemos com tais empreendimentos impingir uma maior agilidade ao processo de tramitação editorial dos manuscritos submetidos, sem perder o alto padrão de qualidade científica e tecnológica que é a marca distintiva de nossa revista.

Os possíveis louros a serem colhidos dos empreendimentos que redundaram na mudança do modo de tramitação "manual" para o modo eletrônico e da periodicidade quadrimestral para trimestral de nosso periódico devem-se ao esforço de uma equipe que trabalhou com afinco e determinação para a consecução de tais propósitos. Cabe salientar que, em detrimento de todas as intempéries, apagões, mudanças, perdas, ganhos, sabores e dissabores vividos nesse intercurso, é com grande alegria e orgulho que hoje anunciamos a nossa estréia nesse novo rumo, cujo benefício - a divulgação da ciência psicológica - visa a servir à comunidade científica da área.

Não posso me furtar ao reconhecimento de que a revista deve a seus predecessores o seu status atual, tal qual o rio deve sua desembocadura ao seu curso: desde a nascente até os percursos mais recentes, todos contribuíram para a formação de seu fluxo atual. A revista é o que é hoje graças aos esforços que cada direção, conselho editorial, consultor ad hoc, equipe técnica, autor, assinante, suporte institucional e apoio de órgãos de fomento que nela investiram. As idéias da tramitação eletrônica e do aumento na periodicidade - que hoje respondem às demandas da modernidade - foram semeadas, amadurecidas e germinadas em gestões anteriores e aguardavam o momento oportuno para a sua eclosão.

Gostaria aqui de prestar meus sinceros agradecimentos à equipe que recentemente colaborou para esta grande estréia e o faço em especial na pessoa de Alex Harlem dos Santos. Espero que com esta fase que agora inauguramos, possamos em breve colher bons frutos e seguir abrilhantando cada vez mais a nossa revista.

Neste número presenteamos os leitores com trabalhos de autores nacionais e internacionais dos diferentes saberes da Psicologia. $\mathrm{Na}$ área do desenvolvimento humano infantil, o estudo de Rita Lopes, Débora de Oliveira, Aline Vivian, Lúcia Bohmgahren, César Piccinini e Jonathan Tudge procura desvelar a riqueza das aquisições ocorridas nos primeiros anos de vida de uma criança e seu impacto sobre os sentimentos maternos. Por sua vez, o artigo de Ethel Battikha, Maria de Faria e Benjamin Kopelman trata das representações psíquicas maternas acerca do nascimento de um bebê com alterações orgânicas graves.

$\mathrm{Na}$ área de aprendizagem e desempenho, Mylena Ribeiro, Grauben de Assis e Sônia Enumo apresentam um interessante estudo sobre as habilidades básicas para o aprendizado da matemática em crianças de aproximadamente 5 anos. Por sua vez, no estudo realizado por Josemberg de Andrade e Jacob Laros os autores propõem um relevante modelo de desempenho escolar para alunos do ensino médio que pode ser utilizado para a elaboração de políticas públicas visando o melhoramento do sistema educacional brasileiro.

Por seu turno, o estudo sobre o complexo fenômeno da drogadição é apresentado no artigo de Elisângela Pratta e Manoel dos Santos, no qual tratam de averiguar as possíveis associações entre uso de drogas e lazer na adolescência. No âmbito da Psicologia Existencial, Éser Pacheco discute em seu artigo as modificações no auto-conceito de indivíduos recém-convertidos ao pentecostalismo, a partir da idéia de "Três Mundos" de Binswanger. Já o artigo de Juliana Porto e Álvaro Tamayo trata da relação entre as estruturas de valores pessoais gerais e laborais. Um estudo transcultural sobre vida sexual é apresentado no artigo de Fernando Cardoso, do qual fizeram parte estudantes universitários de classe média de Israel, Colômbia, Canadá e Brasil. Ainda quanto à questão da sexualidade, um interessante estudo sobre identidades sexuais não-hegemônicas é apresentado no artigo de Ana Madureira e Ângela Branco no qual se ressalta a importância das estratégias pessoais e coletivas utilizadas no cotidiano para lidar com o preconceito e a discriminação.

$\mathrm{Na}$ esfera da saúde mental no trabalho, o artigo de Juliana Bertoletti e Patrícia Cabral apresenta um estudo sobre as experiências laborais dos profissionais de enfermagem e suas conseqüências para a saúde mental desses profissionais.

No âmbito da Psicologia Social, Alejandra Araiza e Gustavo Gisbert apresentam um artigo no qual procuram traçar uma breve aproximação a algumas das transformações e mudanças que o corpo vem sofrendo dentro das teorias da Psicologia e em especial na Psicologia Social. O artigo de Alda de Oliveira e Antonio Roazzi apresenta uma investigação sobre a organização estrutural da representação social do conceito da "doença dos nervos" e como o gênero está associado a essa organização estrutural.

Por fim, Rafael dos Santos nos brinda com sua resenha sobre a coletânea de Labate e Goulart, na qual se discute a temática do uso de substâncias psicoativas a partir de uma perspectiva das ciências humanas, salientando os aspectos psicológicos e socioculturais envolvidos no fenômeno, em detrimento de uma visão linear.

Que a leitura deste, mais uma vez, abra as mentes para novas idéias.

\section{Maria Inês Gandolfo Conceição Editora}

